\title{
GIS-BASED SOLAR AND WIND TURBINE SITE SELECTION USING MULTI-CRITERIA ANALYSIS: CASE STUDY TEHRAN, IRAN
}

\author{
M. Sadeghi ${ }^{\text {a*, M. Karimi }}{ }^{\text {a }}$ \\ ${ }^{a}$ Faculty of Geodesy and Geomatics Engineering, K.N. Toosi-University of Technology, Tehran, Iran \\ (m.sdgh93@gmail.com; mkarimi@kntu.ac.ir)
}

KEY WORDS: solar, photovoltaic, wind turbine, site selection, AHP, LSI

\begin{abstract}
:
Renewable energy has less negative impacts on environment than fossil fuels. Iran has many resources for renewable energy exploitation but because of their high price, it has not been developed. Site selection is an important step for utilizing large investments like solar farms and wind turbines. Multi-criteria evaluation methods are commonly used for site selection. The purpose of this paper is to determine suitable sites for solar farm and wind turbine using GIS and AHP in Tehran, in order to generate a distributed network to increase power network stability. The final land suitability index was grouped in four categories as "most suitable", "suitable", "moderate" and "low suitable". As a result $94.61 \%\left(789939.63 \mathrm{~km}^{2}\right)$ is low suitable, $4.47 \%\left(37337.17 \mathrm{~km}{ }^{2}\right)$ is moderate, $0.59 \%\left(4964.22 \mathrm{~km}^{2}\right)$ is suitable and $0.32 \%\left(2680.70 \mathrm{~km}^{2}\right)$ is the most suitable for building wind turbine and for solar farm, $44.07 \%\left(8116.88 \mathrm{~km}^{2}\right)$ is low suitable, $12.81 \%\left(2359.79 \mathrm{~km}^{2}\right)$ is moderate, $35.10 \%\left(6464.29 \mathrm{~km}^{2}\right)$ is suitable and $8.02 \%$ $\left(1477.28 \mathrm{~km}^{2}\right)$ is the most suitable.
\end{abstract}

\section{INTRODUCTION}

\subsection{Renewable energy in Iran}

Iran is one of the many countries in the world that has the great resources for renewable energy exploitation but because of the low price of fossil fuels, the use of renewable energy has been neglected. Due to the Population growth in the past few years, the need for energy has increased and it will continue to grow. Beside, based on reports, the electricity demand will increase to 200000 MW. Moreover, fossil fuels have negative impact on greenhouse gasses and they cannot meet the need for electricity. Therefore, renewable energy can be a great replacement.

Due to the great geographical position of Iran, it has a good condition for solar energy exploitation. It has been reported that Iran has average solar radiation of $19.23 \mathrm{Mj} / \mathrm{m}^{2}$ and annual average sunshine hours of $3200 \mathrm{~h} /$ year.

The geographical condition of Iran causes the strong air flows. However exploitation of wind energy in Iran has not been developed in recent years. Iran is the only country in the Middle East which has installed wind turbines. Wind power sites are located in Gilan, Khorasan, Ghazvin and Yazd. (Madadi, Hosieni et al.)

In order to have access to secure energy, the use of alternative sources of energy is necessary. Site selection can help finding the best sites with high potential to exploit energy. These complex problems need the evaluation of many decision criteria. For this purpose, MCDM is the method that can be used in these problems (Zoghi, Ehsani et al. 2015). (Gorsevski, Cathcart et al. 2013) used grouped SDSS for evaluating the suitability for wind farm site selection in northwest Ohio. Their research took into account criteria related to environment and economic. The final results showed that nearly $2.4 \%$ of the region has high potential. (Noorollahi, Yousefi et al. 2016) used GIS and SDSS for wind farm site selection in Markazi, Iran. In their study, they first eliminated the unsuitable locations and in the next step they identified the suitable sites and then classified them. (Latinopoulos and Kechagia 2015) used GIS and MCDM method to select appropriate sites for wind farm projects. (Villacreses, Gaona et al. 2017) used GIS and MCDM methods to select the suitable sites to install wind power plants in continental Ecuador. Their research considered selection criteria including meteorological parameters, relief, location and environmental parameters. (Höfer, Sunak et al. 2016) applied GIS-based Analytic Hierarchy Process approach, considering techno-economic, socio-political, and environmental criteria, to improve the wind farm siting assessment. (Zoghi, Ehsani et al. 2015) used fuzzy logic and weighted linear combination for solar site selection in Isfahan, Iran. (Uyan 2013) used AHP for solar farm siting in Karapinar region, Konya/Turkey. (SánchezLozano, Teruel-Solano et al. 2013) used the combination of AHP and GIS for analysing and weighting the factors and TOPSIS for assessment of alternatives. (Tahri, Hakdaoui et al. 2015) used the combination of GIS and AHP to assess the suitability of a certain set of locations for exploiting the solar energy. (Asakereh, Soleymani et al. 2017) used GIS and fuzzyAHP method to prioritize the Khuzestan province in Iran to install PV farms. They used fuzzy logic and fuzzy membership functions to create the techno-economic and environmental criteria layer and AHP to weight criteria and create the final map of land suitability for solar farm. (Yushchenko, de Bono et al. 2017) used GIS and MCDM method to estimate the solar electricity generation in ECOWAS region in West Africa based on geographical and technical potentials. Their study take both grid connected solar systems and off-grid solar systems into consideration.

\footnotetext{
* Corresponding author
} 


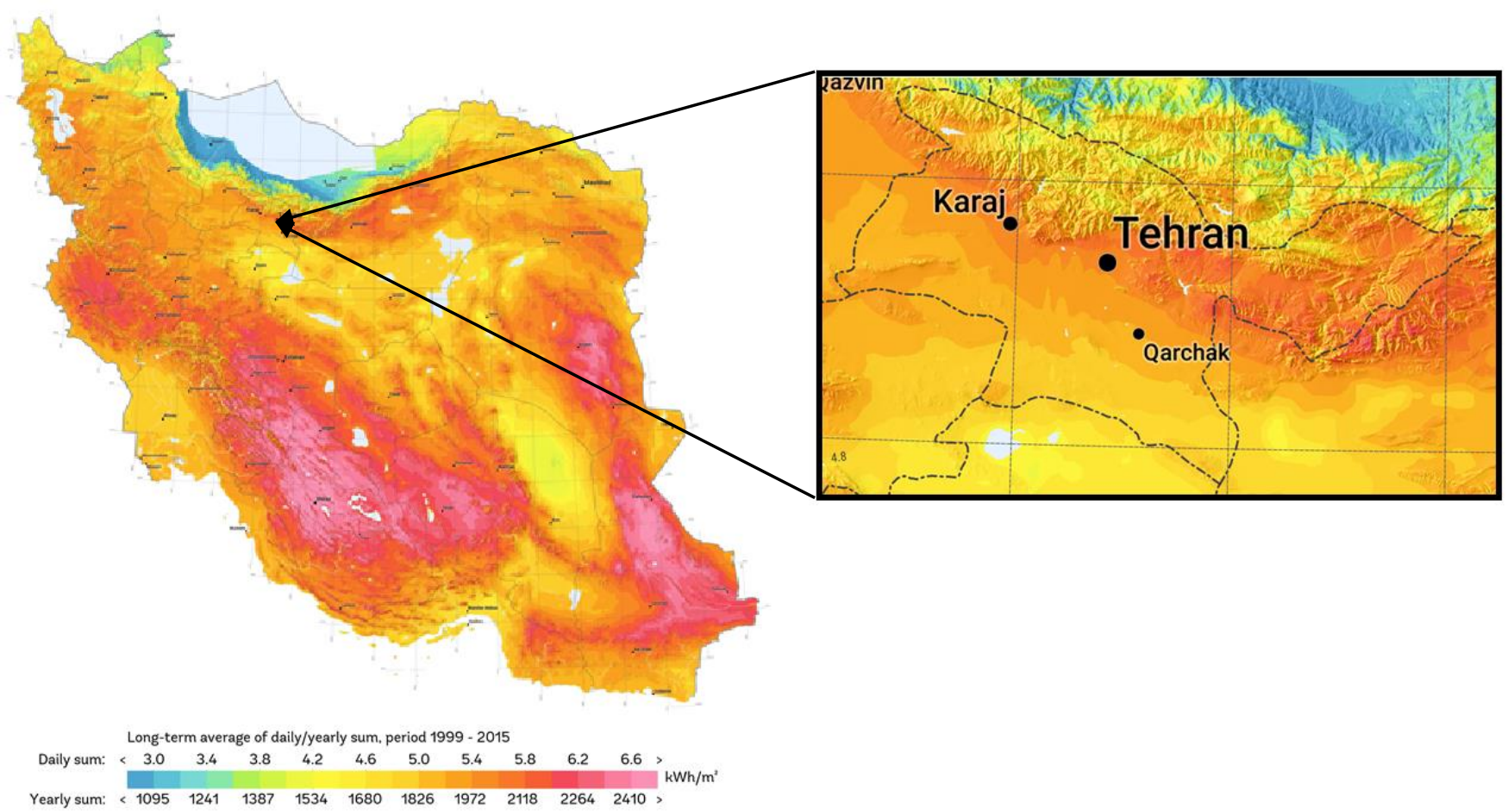

Figure 1. Iran solar radiation annual means (source: Direct normal irradiation, 1994-2015)

\section{MATERIAL AND METHODS}

\subsection{Study Area}

Tehran is located between latitudes $35^{\circ} 34^{\prime}$ to $35^{\circ} 51^{\prime}$ north and longitudes $51^{\circ} 6^{\prime}$ to $51^{\circ} 38^{\prime}$ east and covers the area of 1404.788 square kilometres. As shown in Figure 1. Tehran has more than 122 sunny days in a year and has high solar radiation. Therefore it is a suitable region for building solar panels. According to data acquired from synoptic stations located in Tehran and suburbs, wind speed is nearly sufficient in eastern part of Tehran.

\subsection{Definition of factors and criteria}

The first step in solving an evaluation problem is defining the factors and criteria. Factors which are selected are based on researches and expert opinions. The factors which are selected for solar site selection are: climatic, location and geomorphology (Zoghi, Ehsani et al. 2015) and factors for wind turbine site selection are environmental and economical factors. Each factor is divided into some criteria and each criteria is divided into some sub- criteria. The tree structure of factors and criteria of solar and wind turbine site selection are shown in Figure 2. and Figure 3., respectively.

\subsubsection{Solar site factors}

Sunshine hours: sunny hours mean the number of hours that the sun is in the sky. This parameter indirectly represents the amount of energy that is received (Zoghi, Ehsani et al. 2015).

- Solar radiation: This parameter is the most important parameter. This parameter means the amount of energy received at one point of the surface of the earth and it depends on various factors including: latitude and longitude, humidity, evaporation, sun angle and etc. (Zoghi, Ehsani et al.
2015). In this study, solar radiation map was made using GIS software.

Humidity: humidity is the biggest absorber of sun energy. Places with high humidity percentage are not suitable for building a solar farm (Zoghi, Ehsani et al. 2015).

Distance to city: building a solar farm near to the city decreases the expenses of transportation and energy loss. However, according to the city development law, building a solar farm in a 500 meter buffer is not allowed (Zoghi, Ehsani et al. 2015).

Distance to power lines: building the industrial equipment near the power lines avoids voltage dropping, increases the overall efficiency, decreases the power loss and therefore decreases the environmental pollution (Zoghi, Ehsani et al. 2015).

Distance to transportation network: building a solar farm near to roads decreases the expenses of utility and support group transportation. The industrial equipment is not allowed to be built in the 250 meters buffer from major roads (Zoghi, Ehsani et al. 2015).

- $\quad$ Elevation: elevation has an inverse relationship with atmosphere thickness. Thicker atmosphere has thicker components therefore more energy would be absorbed or reflected. Therefore highlands would have more potential in this case (Zoghi, Ehsani et al. 2015).

- $\quad$ Slope: land potential for industrial usages can decrease by increasing slope. Optimum slope should be lower than 3\% (Uyan 2013).

Aspect: solar panels should be oriented in a way that receives as much as energy during the day. The best aspects are south, southwest and south east relatively (Tahri, Hakdaoui et al. 2015). 
Land use: land use is an environment factor for solar site selection (Uyan 2013, Zoghi, Ehsani et al. 2015). In this study, we consider land use in four categories: arid, grass, orchard and woods and cultivation.



Figure 2. Criteria and factors for solar site selection

\subsubsection{Solar site constraints}

Constraints are limiting factors that define unsuitable sites and should be subtracted first. Solar site constraints are explained below (Uyan 2013, Zoghi, Ehsani et al. 2015):

- $\quad$ Distance to city $=500 \mathrm{~m}$

- $\quad$ Distance from major roads $=100 \mathrm{~m}$

- $\quad$ Distance to protected areas $=500 \mathrm{~m}$

- $\quad$ Distance to wetlands and forests $=500 \mathrm{~m}$

\subsubsection{Wind turbine factors}

- Wind speed $(\mathrm{m} / \mathrm{s})$ : this is the most important factor. The average wind speed of the region should meet the wind speed needed for moving the small wind turbines that are used in the city (Noorollahi, Yousefi et al. 2016).

- $\quad$ Land use: In this study, we consider land use in four categories: arid, grass, orchard and woods and cultivation (Gorsevski, Cathcart et al. 2013).

- Distance to power lines (Noorollahi, Yousefi et al. 2016)

- Distance to transportation network: the Euclidean distance is calculated. Building wind turbine is not permitted in the 500 meter buffer form the major roads (Noorollahi, Yousefi et al. 2016).

Distance to city: building a wind turbine near the city causes pollution. Building a wind turbine is not permitted in the 500 meter buffer form the city.

\subsubsection{Wind turbine constraints}

Wind turbine constraints are explained below (Gorsevski, Cathcart et al. 2013, Noorollahi, Yousefi et al. 2016):

- Distance to power lines $=250 \mathrm{~m}$

- $\quad$ Distance from major roads $=500 \mathrm{~m}$

- $\quad$ Distance to city $=500 \mathrm{~m}$

- $\quad$ Distance from Airport $=250 \mathrm{~m}$

- $\quad$ Elevation $=$ more than $2000 \mathrm{~m}$

- $\quad$ Slope $=$ more than $15 \%$ 


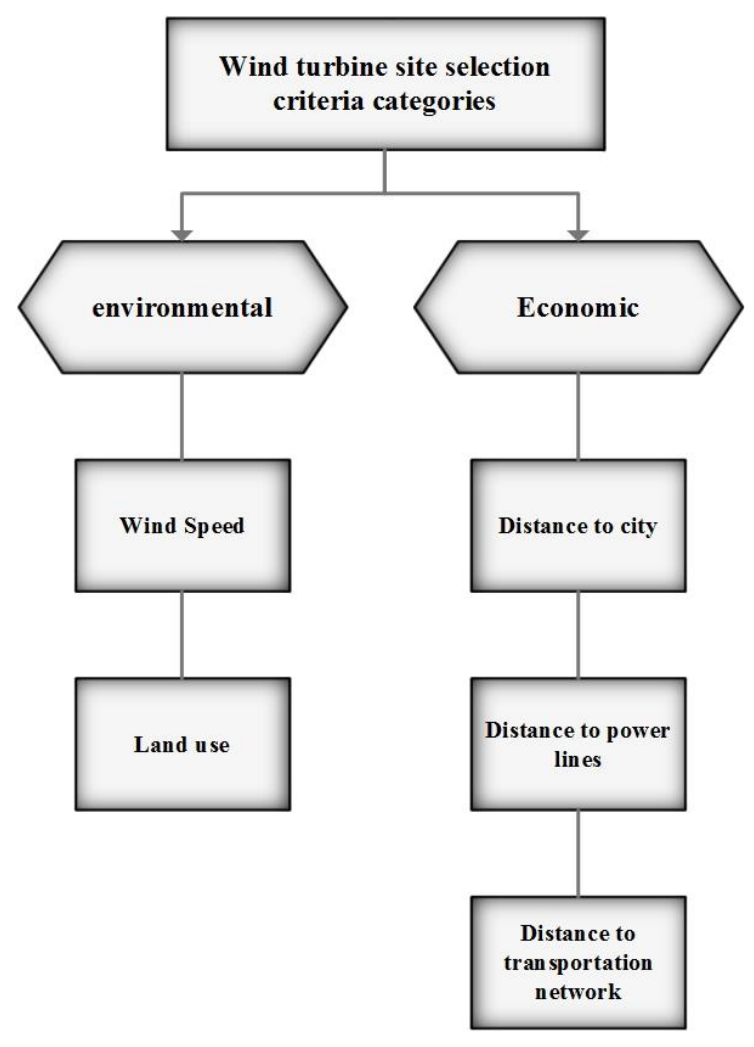

Figure 3. Criteria and factors for wind turbine site selection

\subsection{Weighting criteria}

In this paper, AHP is used for weighting the criteria. AHP has three phases: analysis, comparison and priority composition. In the first phase the criteria and sub-criteria are determined and a tree structure for them is made. In the second phase the comparison matrix is made and the criteria are compared 2-by-2 and they are scored (Zoghi, Ehsani et al. 2015) from 1-9 based on the scale of Saaty (Saaty 1980). The comparison matrix (Equation 1.) for $\mathrm{n}$ criteria is composed as follow (SánchezLozano, Teruel-Solano et al. 2013):

$$
A=\underset{A_{n}}{A_{1}}\left[\begin{array}{ccc}
a_{11} & \cdots & a_{1 n} \\
\vdots & \ddots & \vdots \\
a_{n} & \cdots & a_{n n}
\end{array}\right]
$$

Then the comparison matrix is normalized; each element is divided by the sum of its column. In the end the average of each row is calculated and the relative weight of each criterion is defined. Afterwards, the consistence index of the matrix is calculated (Equation 2.).

$$
C I=\frac{\lambda_{\max }-n}{n-1}
$$

The next step is to calculate the consistency ratio (Equation 3.).

$$
C R=\frac{C I}{R I}
$$

Where $\quad \mathrm{RI}=$ random consistency index for different values of $n$ (Table 1.)

If $\mathrm{CR} \geq 0.1$, the consistency degree is satisfactory but if the $\mathrm{CR}<0.1$ the matrix is inconsistent (Uyan 2013).

Where $\quad \lambda_{\max }=$ Eigen value of the matrix $\mathrm{n}=$ number of criteria

\begin{tabular}{|l|l|l|l|l|l|l|l|l|l|l|}
\hline $\boldsymbol{n}$ & $\mathbf{1}$ & $\mathbf{2}$ & $\mathbf{3}$ & $\mathbf{4}$ & $\mathbf{5}$ & $\mathbf{6}$ & $\mathbf{7}$ & $\mathbf{8}$ & $\mathbf{9}$ & $\mathbf{1 0}$ \\
\hline $\boldsymbol{R I}$ & 0.00 & 0.00 & 0.58 & 0.90 & 1.12 & 1.24 & 1.32 & 1.41 & 1.45 & 1.49 \\
\hline
\end{tabular}




\subsection{Combination of criteria}

In this study, LSI was used to combine criteria and calculate the overall score and land suitability of the study area. The land suitability index for solar farm is calculated using Equation 4. (Uyan 2013):

$$
\begin{gathered}
L S I_{s}=\left[A *\left(\left(\sum_{j=1}^{n} A_{j} C_{W i} * A_{j} S C_{w i}\right)\right)\right]+\left[B *\left(\left(\sum_{j=1}^{m} B_{j} C_{W i} * B_{j} S C_{w i}\right)\right)\right] \\
+\left[C *\left(\left(\sum_{j=1}^{k} C_{j} C_{W i} * C_{j} S C_{w i}\right)\right)\right]
\end{gathered}
$$

Where

LSI = land suitability index $\mathrm{n}=$ number of criteria in climatic objective $\mathrm{A}=$ weight index of climatic objective $\mathrm{A}_{\mathrm{j}} \mathrm{CW}_{\mathrm{i}}=$ weighted index of criteria related to climatic objective (sunshine hours, sun radiation and humidity)

$\mathrm{A}_{\mathrm{j}} \mathrm{SC}_{\mathrm{wi}}=$ weighted index of sub-criteria related to criteria in climatic objective

$\mathrm{m}=$ number of criteria in objective location

$\mathrm{B}=$ weight index of location objective

$\mathrm{B}_{\mathrm{j}} \mathrm{C}_{\mathrm{W}}=$ weighted index of criteria related to location objective (distance to city, distance to power line, distance to major roads, land use) $\mathrm{B}_{\mathrm{j}} \mathrm{SC}_{\mathrm{wi}}=$ weighted index of sub-criteria related to criteria in location objective

$\mathrm{k}=$ number of criteria in geomorphological objective

$\mathrm{C}=$ weight index of geomorphological objective
$\mathrm{C}_{\mathrm{j}} \mathrm{C}_{\mathrm{W}}=$ weighted index of criteria related to geomorphological objective (elevation, slope, aspect)

$\mathrm{C}_{\mathrm{j}} \mathrm{SC}_{\mathrm{wi}}=$ weighted index of sub-criteria related to criteria in geomorphological objective

The calculated weights with AHP for climatic objective are

\begin{tabular}{|c|c|c|c|c|c|c|}
\hline Goal & Objective & weight & Criteria & weight & Sub-criteria & weight \\
\hline \multirow[t]{12}{*}{ Land Suitability } & \multirow{12}{*}{$\begin{array}{l}\text { Climatic } \\
\text { (A) }\end{array}$} & \multirow[t]{12}{*}{0.7235} & \multirow[t]{4}{*}{ Sunshine hours } & \multirow[t]{4}{*}{0.2828} & $<2900$ & 0.0803 \\
\hline & & & & & $2900-2950$ & 0.1756 \\
\hline & & & & & $2950-3000$ & 0.2681 \\
\hline & & & & & $>3000$ & 0.4760 \\
\hline & & & \multirow[t]{4}{*}{ Solar radiation } & \multirow[t]{4}{*}{0.6434} & $<900000$ & 0.0404 \\
\hline & & & & & $900000-1200000$ & 0.1166 \\
\hline & & & & & $1200000-1500000$ & 0.2195 \\
\hline & & & & & $>1500000$ & 0.6235 \\
\hline & & & \multirow[t]{4}{*}{ Humidity (\%) } & \multirow[t]{4}{*}{0.0738} & $<40$ & 0.5254 \\
\hline & & & & & $40-42.5$ & 0.2574 \\
\hline & & & & & $42.5-45$ & 0.1493 \\
\hline & & & & & $>45$ & 0.0679 \\
\hline
\end{tabular}
summarized in Table 2.

Table 2. Climatic objective for solar farm site selection

The land suitability index for wind turbine is calculated using Equation 5.

$$
L S I_{w}=\left[A *\left(\left(\sum_{j=1}^{n} A_{j} C_{W i} * A_{j} S C_{w i}\right)\right)\right]+\left[B *\left(\left(\sum_{j=1}^{m} B_{j} C_{W i} * B_{j} S C_{w i}\right)\right)\right]
$$

$\mathrm{B}_{\mathrm{j}} \mathrm{SC}_{\mathrm{wi}}=$ weighted index of sub-criteria related to criteria in economic objective

Calculated weights with AHP for environmental objective are summarized in Table 3.

Where $\quad n=$ number of criteria in environmental objective $\mathrm{A}=$ weighted index of environmental objective $\mathrm{A}_{\mathrm{j}} \mathrm{C}_{\mathrm{Wi}}=$ weighted index of criteria related to environmental objective (wind speed, land use) $\mathrm{A}_{\mathrm{j}} \mathrm{SC}_{\mathrm{wi}}=$ weighted index of sub-criteria related to criteria in environmental objective $\mathrm{m}=$ number of criteria in economic objective $\mathrm{B}=$ weighted index of economic objective $\mathrm{B}_{\mathrm{j}} \mathrm{C}_{\mathrm{Wi}}=$ weighted index of criteria related to economic objective (distance to power lines, distance to major roads, distance to city) 


\begin{tabular}{|c|c|c|c|c|c|c|}
\hline Goal & Objective & weight & Criteria & weight & Sub-criteria & weigh \\
\hline \multirow[t]{8}{*}{ Land Suitability } & \multirow{8}{*}{$\begin{array}{l}\text { Environmental } \\
\text { (A) }\end{array}$} & \multirow[t]{8}{*}{0.8333} & Wind speed $(\mathrm{m} / \mathrm{s})$ & \multirow[t]{4}{*}{0.2828} & $<2$ & 0.0524 \\
\hline & & & & & $2-2.75$ & 0.0524 \\
\hline & & & & & $2.75-3.5$ & 0.2508 \\
\hline & & & & & $>3.5$ & 0.6443 \\
\hline & & & \multirow[t]{4}{*}{ Land use } & \multirow[t]{4}{*}{0.6434} & arid & 0.521 \\
\hline & & & & & cultivation & 0.3064 \\
\hline & & & & & grass & 0.1262 \\
\hline & & & & & orchard and & 0.0465 \\
\hline
\end{tabular}

Table 3. Environmental objective for wind turbine site selection

\section{RESULTS AND CONCLUSIONS}

In order to make efficient use of distributed generations to increase network stability and reliability, decrease power loss and improve voltage profile, we need to find places with high potential for solar farm and wind turbine.

The restrictive constraints were applied for solar site and wind turbine primarily. In order to calculate the suitability index, AHP was used. A land suitability index was determined for both solar site and wind turbine. The final index was then categorized in "best suitable", "suitable", "moderate" and "low suitable". Figure 4. and Figure 5.

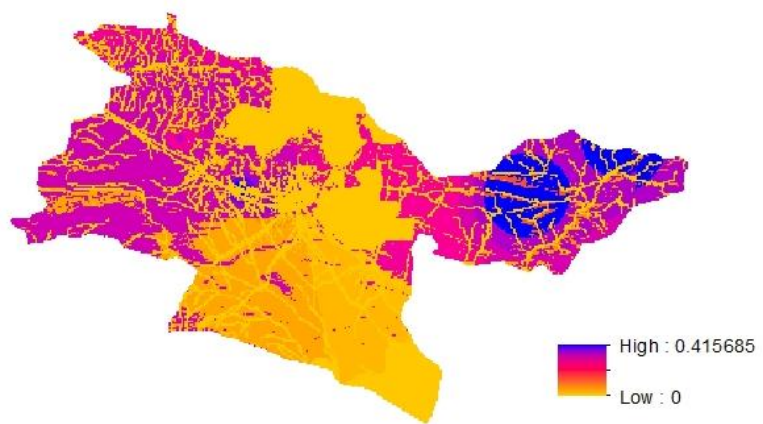

(a)

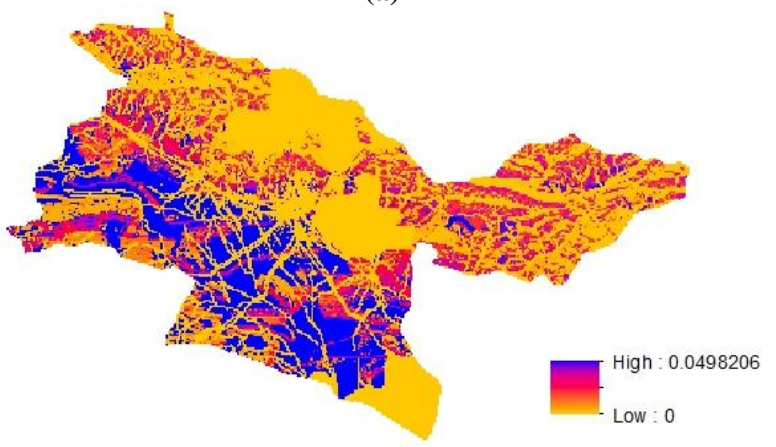

(c)
As a result, the total area of $1477.28 \mathrm{~km}^{2}(8.02 \%)$ is "best suitable", $6464.29 \mathrm{~km}^{2}(35.10 \%)$ is "suitable", $2359.79 \mathrm{~km}^{2}$ $(12.81 \%)$ is "moderate" and $8116.88 \mathrm{~km}^{2}(44.07 \%)$ is "low suitable" for building solar farm.

Furthermore, the total area of $2680.70 \mathrm{~km}^{2}(0.32 \%)$ is "best suitable", $4964.22 \mathrm{~km}^{2}(0.59 \%)$ is "suitable", $37337.17 \mathrm{~km}^{2}$ $(4.47 \%)$ is "moderate" and $789939.63 \mathrm{~km}^{2}(94.61 \%)$ is "low suitable" for building wind turbines. As a result, eastern part of Tehran province has potential for building wind turbine.

As shown in Figure 6. places with value 1 are the most suitable places for building both solar farm and wind turbine.

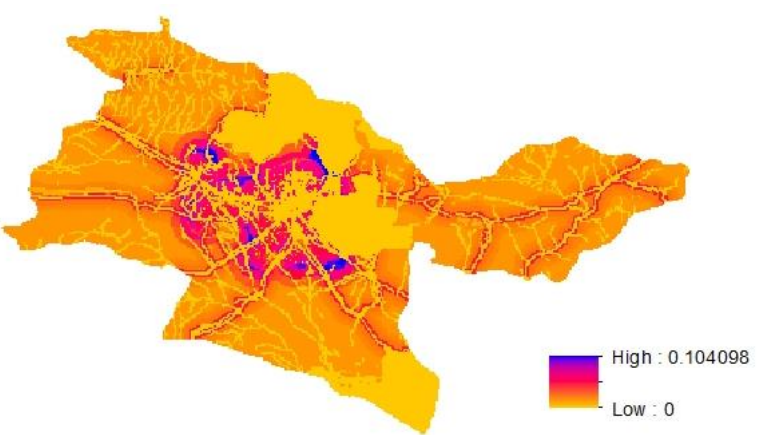

(b)

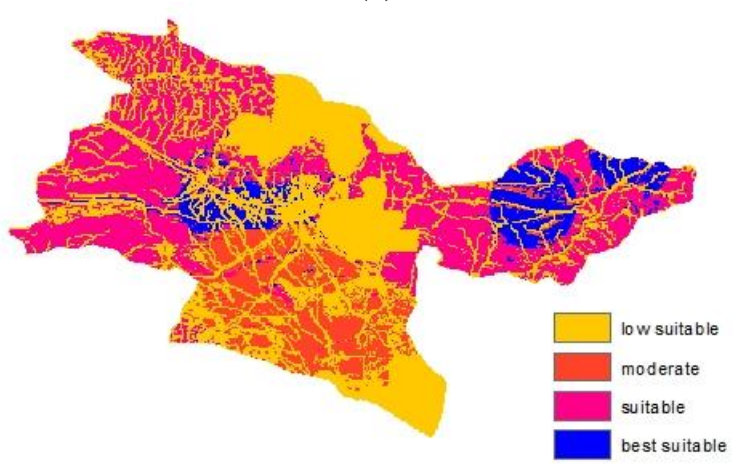

(d)

Figure 4. LSI for (a)climatic (b)location (c)geomorphological factors. (d) final suitability map for solar farm site selection. 


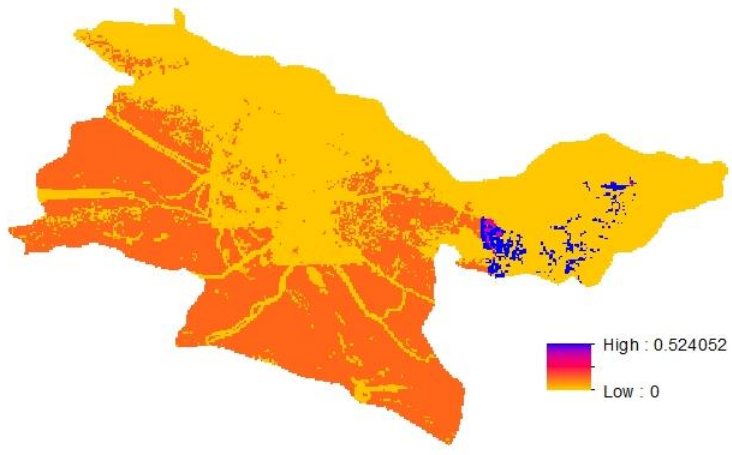

(a)

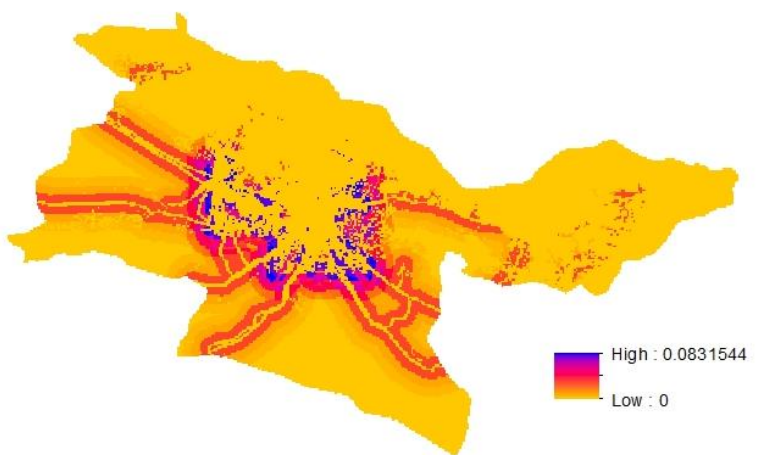

(b)



(c)

Figure 5. LSI for (a) environmental (b) economic factors. (c) final suitability map for wind turbine site selection.

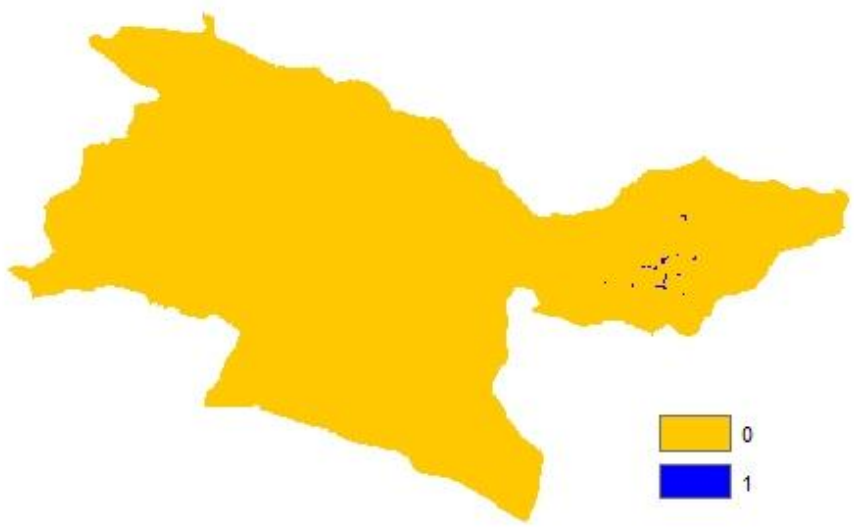

Figure 6. Best suitable locations for solar farm and wind turbine

\section{REFERENCES}

Direct normal irradiation. (1994-2015). Figure 1. retrieved from http://globalsolaratlas.info

Asakereh, A., et al. (2017). "A GIS-based Fuzzy-AHP method for the evaluation of solar farms locations: Case study in Khuzestan province, Iran." Solar Energy 155: 342-353.

Gorsevski, P. V., et al. (2013). "A group-based spatial decision support system for wind farm site selection in Northwest Ohio." Energy Policy 55: 374-385.
Höfer, T., et al. (2016). "Wind farm siting using a spatial Analytic Hierarchy Process approach: A case study of the Städteregion Aachen." Applied energy 163: 222-243.

Latinopoulos, D. and K. Kechagia (2015). "A GIS-based multicriteria evaluation for wind farm site selection. A regional scale application in Greece." Renewable Energy 78: 550-560.

Madadi, M., et al. "A review on renewable energy resources in Iran."

Noorollahi, Y., et al. (2016). "Multi-criteria decision support system for wind farm site selection using GIS." Sustainable Energy Technologies and Assessments 13: 38-50. 
Saaty, T. (1980). "The Analytic Hierarchy Process, planning, priority setting, resource allocation, McGrow-Hill." Inc. New York, NY.

Sánchez-Lozano, J. M., et al. (2013). "Geographical Information Systems (GIS) and Multi-Criteria Decision Making (MCDM) methods for the evaluation of solar farms locations: Case study in south-eastern Spain." Renewable and Sustainable Energy Reviews 24: 544-556.

Tahri, M., et al. (2015). "The evaluation of solar farm locations applying Geographic Information System and Multi-Criteria Decision-Making methods: Case study in southern Morocco." Renewable and Sustainable Energy Reviews 51: 1354-1362.

Uyan, M. (2013). "GIS-based solar farms site selection using analytic hierarchy process (AHP) in Karapinar region, Konya/Turkey." Renewable and Sustainable Energy Reviews 28: 11-17.

Villacreses, G., et al. (2017). "Wind farms suitability location using geographical information system (GIS), based on multicriteria decision making (MCDM) methods: The case of continental Ecuador." Renewable Energy 109: 275-286.

Yushchenko, A., et al. (2017). "GIS-based assessment of photovoltaic (PV) and concentrated solar power (CSP) generation potential in West Africa." Renewable and Sustainable Energy Reviews.

Zoghi, M., et al. (2015). "Optimization solar site selection by fuzzy logic model and weighted linear combination method in arid and semi-arid region: A case study Isfahan-IRAN." $\underline{\text { Renewable and Sustainable Energy Reviews. }}$ 